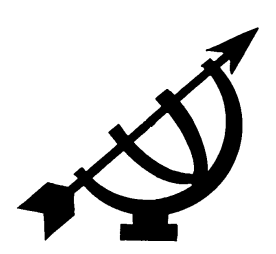

\title{
Power: towards a third generation definition
}

\author{
Johan Zaaiman \\ School for Social and Government Studies \\ Potchefstroom Campus \\ North-West University \\ POTCHEFSTROOM \\ E-mail: Johan.Zaaiman@nwu.ac.za
}

\section{Abstract \\ Power: towards a third generation definition}

Power is a well-established concept in the social sciences especially in the political sciences. Although it is widely used in scientific discourse, different definitions and perspectives prevail with regard to it. This article aims to explore the possibilities of taking the debate further towards a third generation definition of social power. Although first generation definitions (associated with Weber and Dahl) and second generation definitions (associated with inter alia Giddens and Morriss) are still widely used in the academic field, they do not reflect the depth of the continuous debate on the concept of power. Viewpoints, especially with regard to agency and freedom, are not reflected in current definitions. To this can also be added the important dynamic relationship between power and change. This article summarises the important aspects of power debates relevant for defining power and discusses possible ways in which this can be accommodated in a definition of power. The current debate on the relationship between power and change is also reinterpreted with regard to defining social power. The article concludes by proposing necessary aspects of a third generation definition of power and suggests such a definition.

\section{Opsomming}

\section{Mag: op weg na 'n derdegenerasiedefinisie}

Mag is 'n goed gevestigde konsep in die sosiale wetenskappe veral in die politieke wetenskappe. Hoewel dit algemeen in wetenskaplike redevoering gebruik word, bly verskillende definisies en perspektiewe daaroor bestaan. Hierdie artikel onder- 
soek die moontlikhede om die debat verder te neem op weg na 'n derdegenerasiedefinisie. Hoewel eerstegenerasiedefinisies (geassosieer met Weber en Dahl) en tweedegenerasiesdefinisies (geassosieer met onder andere Giddens en Morriss) steeds algemeen in die akademiese veld gebruik word, reflekteer hulle nie die diepte van die volgehoue debat oor die konsep "mag" nie. Gesigspunte, veral ten opsigte van agentskap en vryheid, word nie gereflekteer in huidige definisies nie. Hierby kan die belangrike dinamiese verhouding tussen mag en verandering gevoeg word. Hierdie artikel som die belangrikste aspekte van die debatte, wat verband hou met die definiëring van "mag", op en bespreek die verskillende wyses hoe dit in die definisie van mag geakkommodeer kan word. Die huidige debat oor die verhouding tussen mag en verandering word ook herinterpreteer met betrekking tot die definiëring van sosiale mag. Die artikel sluit af deur die nodige aspekte vir 'n derdegenerasiedefinisie van mag voor te stel en dus 'n definisie te suggereer.

\section{Introduction}

The debates with regard to power in the social sciences are intensive and widespread. Writers on power differ in their approach to this concept. Some writers contribute to our understanding of power without embedding themselves in the conceptual debates. They use existing or other useful definitions or no definition at all. But many writers contribute to the definition debate itself - directly or indirectly. A problem in these debates is that many of the contributions are individualistic and do not necessarily contribute to integrate the different views of power. This article does not overcome this problem. It is also a very specific view on power referring to various contributions to the debate, but proposing a very specific definition.

\section{The first and second generation definitions}

In this article it is proposed that we are moving towards a third generation definition of power. The first generation definitions of power were the typical early "power over" definitions. Although Max Weber doesn't use the word "over" it is implicated in his definition. Weber define power as that chance in a social relationship in which somebody can carry out his or her will even against resistance, irrespective the basis or the chance (Weber, 1947:152 and Weber 1962:117). One of the most quoted definitions of power was formulated by Robert Dahl. He described power as follows: "A has 
power over $B$ to the extent that he can get $B$ to do something that $B$ would not otherwise do." (Lukes, 1986:2.)1

Raymond Aron, Dennis Wrong and Aovin I. Goldman used the same kind of definitions. But their definitions included new elements with regard to power. This formed the basis on which eventually the second generation of definitions developed. These definitions moved away from the view that power is about the impact of $A$ on $B$, to the view that power is a capacity to bring about effects. Aron successfully explained that power "... extends over certain men or certain groups, and not over others; it exercises command over certain kinds of behaviour by the objects of power, but not over others" (Aron, 1986:260). Power, therefore can't be exercised over a person but only over a person's behaviour. In addition Dennis Wrong formulated power as the ability of some persons to bring about intended and anticipated effects on others (Wrong, 1979:2). This established the second generation definitions on power, which are described as "power to". Especially Anthony Giddens (1991) settled this notion of power as a capacity by formulating power as an agent with the ability to make a difference in the present state of affairs.

In the 1990s the theoretical debates on power developed further with the book of Peter Morriss (1987) Power: a philosophical analysis playing an important role in it. This lead to second editions of Morriss's book in 2002 and also of Lukes book Power: a radical view in 2005. Some of the central issues in these books are those that, in my opinion, start to formulate aspects of third generation definitions of power.

But alongside the focused debates on the definition other debates on power thrive. Actually, many of the major debates with respect to power, in the past and now, are about power-related issues that are not directly related to the definition. Typically it is about who or what is exercising or exerting power, what resources, motives and interests are in the play, what is the limitations of power, what is its

1 However, this widely used definition of Dahl was only one of his definitions. He also formulated a general description of power which covers interpersonal relations and relations among social collectivities. He writes: "At the most general level, power terms in modern social science refer to subsets of relations among social units such that the behaviours of one or more units ... depend in some circumstances on the behaviour of other units ..." (Dahl, 1986:40). 
appearance and characteristics, how does it changes and how must it be evaluated.

The following table lists these issues and some of the well-known writers who debated these issues:

\section{Table 1}

\begin{tabular}{|l|l|}
\hline $\begin{array}{l}\text { Who or what is exercising or exerting } \\
\text { power }\end{array}$ & $\begin{array}{l}\text { Foucault, Galbraith, Giddens, } \\
\text { Gramsci, Lenin, Lipset, Lukes, Mann, } \\
\text { Marx, Mill, Morriss, Poulantzas, } \\
\text { Russell, Simmel, Wrong }\end{array}$ \\
\hline $\begin{array}{l}\text { What resources, motives and interests } \\
\text { are in the play }\end{array}$ & $\begin{array}{l}\text { Arendt, Bachrach, Barat, Dahl, } \\
\text { Foucault, Freud, Galbraith, Giddens, } \\
\text { Habermas, Hunter, Lenski, Lukes, } \\
\text { Machiavelli, Morriss, Parsons, Simmel, } \\
\text { Wrong }\end{array}$ \\
\hline What is the limitations of power & $\begin{array}{l}\text { Aron, Goldman, Lukes, Morriss, } \\
\text { Parsons, Simmel }\end{array}$ \\
\hline $\begin{array}{l}\text { What is its appearance and character- } \\
\text { istics }\end{array}$ & $\begin{array}{l}\text { Arendt, Dahl, De Jouvenel, Galbraith, } \\
\text { Morriss, Parsons, Wrong }\end{array}$ \\
\hline How does it changes & $\begin{array}{l}\text { Lenski, Russell, Weber, Wrong } \\
\text { How must it be evaluated }\end{array}$ \\
\hline
\end{tabular}

Some of the debates, with regard to the issues listed in Table 1, also contributed towards the development of possible third generation definitions on power. These debates assisted in maturing the debate on the nature of the concept power.

The nature of the power is important with regard to third generation definitions: the development of a third generation definition is not the same as the major conceptual progress from "power over" to "power to", as we found in the first to the second generation definitions. The third generation definitions rather illustrate a more comprehensive defining of power especially with regard to related concepts like change and influence. But from current debates, it is clear that some other concepts are also important in these relationships. The following sections address the nature of these relationships and contribute to the conclusion of this article which suggests a possible definition of power, accommodating these issues. 


\section{Power and change}

In different ways Morriss and Lukes raised indirectly the problematic relationship between power and change in their new books. However, Sartre has a formulation which most directly refer to this interesting relationship:

In so far as man is immersed in the historical situation, he does not even succeed in conceiving of the failures and lacks in a political organization or determined economy; this is not, as is stupidly said, because he 'is accustomed to it', but because he apprehends it in its plenitude of being and because he can not even imagine that he can exist in it otherwise. For it is necessary here to reverse common opinion and on the basis of what it is not, to acknowledge the harshness of a situation or the suffering which it imposes, both of which are motives for conceiving of another state of affairs in which things would be better for everybody. It is on the day that we can conceive of a different state of affairs that a new light falls on our troubles and our suffering and that we decide that these are unbearable. (Sartre, 1956:561.)

Sartre is making the important point that only in a context where the possibility of change can be imagined, can power operate.

To take Sartre's view further, when, for some or other reason, change becomes impossible, the power relationship ends. If the ability to effect something (to bring about change) is not possible, power does not exist. This was confirmed in a research investigating the influence of leaders on change in a local community in South Africa (Zaaiman, 2001:374). In this research 32 local leaders were interviewed in October and November 2000. This was a few months after the new and final boundaries of the new local government of their community was stipulated by the demarcation board. In the discussion on the demarcation issue it soon became clear that the leaders no longer viewed it as a power issue. For them it became just a reality to live by. Before the demarcation most of them lobbied for alternative boundaries. They played a powerful role trying to influence the process. The moment it became clear that they could not influence the process anymore, they abandoned that initiative. Therefore it can be concluded that power exist only in a situation where the possibility of change is present. Power is aimed at change - to stop it, to start it or to direct it. This can only be done where the possibility of change exists. Power arises when change is possible. This is a necessary precondition for power to exist. But for power to 
be exercised, agents are necessary. They are identified in the following section.

\section{Agents}

Agents cause an effect. A power agent or power (something with power) is therefore something that has the ability to cause an effect on affairs and people. It is customary to see people and groups as agents. In the debate on power other agents also have been identified. Some examples of that are discussed in this section.

\subsection{Agency in systems}

For Parsons power is a generalised capacity of units in a system to secure the performance of binding obligations. It holds for obligations that are legalised with reference to their bearing on collective goals. Further there is the presumption that in the case of recalcitrance sanctions will be enforced if resistance is encountered. These sanctions are not enforced by a specific agency (Parsons, 1986:103). Habermas formulates Parsons definition of power more plainly. He says that for Parsons, power is the generalised capacity of a social system to get things done on behalf of collective goals. Agreement produces the power that is fixed in binding decisions by the use of social resources (Habermas, 1986:76). Parsons view the social system as an agent exercising power.

Giddens criticise Parsons's definition as follows:

In associating power with so-called 'collective goals', Parsons sacrifices part of the insight that the concept of power has no intrinsic relation to that of interest. If power has no logical connection with the realization of sectional interests, neither does it have any with the realization of collective interests or 'goals'. More substantively, Parsons's concentration upon normative consensus as the foundation of the integration of societies leads him seriously to underestimate the significance of contestation of norms; and of the manifold circumstances in which force and violence, and the fear of them, are directly involved in the sanctioning of action. (Giddens, 1991:257.)

Giddens therefore rejects Parsons argument in which he identifies the whole social system as an agent of power.

But Foucault (1986) also viewed power not primarily forthcoming from individuals, but from the functioning of society. He says that rights (freedom clauses) is traditionally viewed as instruments to 
temper power, but in reality these rights were instruments of domination used to advance power (Foucault, 1986:229). The fact that rights are used in such a way and a truth is produced thereby to legitimise the power relationships, leads to the full domination of people - of their actions and their thoughts. Lukes put Foucault's standpoint as follows: "People thus become subjects in a double sense: subject to others 'by control and dependence' and tied to their 'own identity by consciousness and self-knowledge'." (Lukes, 1986:11.) Foucault stresses that the freedom of people are farreachingly limited by society. He says people are controlled from outside by a variety of power instruments, they are deprived of their independence and their identity is socially constructed (Lukes, 1986:11).

\subsection{Agency in different dimensions}

Giddens is correct when he criticises a description making the agent of power too general. Foucault, on the other hand, correctly identifies aspects of society as agents of power. Lukes also refers to this in his description of, what he calls the three-dimensional perspective on power.

Lukes integrates the different kinds of agents by referring to different dimensions of power. The first two dimensions he describes refer mainly to rulers and the third dimension to the role of social forces and institutions. Firstly he refers to the one-dimensional perspective on power:

... this first, one-dimensional, view of power involves a focus on behaviour in the making of decisions on issues over which there is a conspicuous conflict of (subjective) interests, seen as express policy preferences, revealed by political participation (Lukes, 1974:15).

He refers to the studies of Hunter and Dahl as examples in which the preferences of some agents rule over the preferences of others on key issues. The focus is here on the visible aspects of the power struggle. Secondly he refers to the two-dimensional perspective of power which was developed by Bachrach and Baratz (1963). He writes that this perspective of power:

... allows for consideration of the ways in which decisions are prevented from being taken on potential issues over which there is an observable conflict of (subjective) interests, seen as embodied in expressed policy preferences and sub-political grievances (Lukes, 1974:20). 
All exercises of power do not occur conspicuously. Agents of power can determine which issues occur on the agenda and keep issues of their choice outside the decision-making level. Thirdly he writes on the three-dimensional perspective of power that he has developed himself. This perspective of power looks especially at the influence of social powers and institutions on the political decision-making level. Lukes writes that this perspective: "... allows for consideration of the many ways in which potential issues are kept out of politics, whether through the operation of social forces and institutional practices or individuals' decisions" (Lukes, 1974:24). The decisionmaking process is bedded in the social structure that has an important influence on what happens in the process. Social structures and institutions can therefore also be agents of power.

\subsection{Agency and interests}

Implied in Lukes description of the different dimensions of power is how difficult it is to answer the question: "Who can influence the interests of whom adversely?" Influence is complicated and therefore it is difficult to link it directly with interests. With humans as agents such links could be considered, but in the case of social structures it becomes even more difficult. The best is not to define power in view of the interests of agents.

It is therefore clear that Poulantzas's definition of power referring to the power as the ability of a social class to serve its specific interests, is problematic (Pulantzas, 1986:144-155). Firstly interests problematise the definition and secondly Poulantzas excludes power as occurring on a personal level. He limits the meaning of power too much. Social classes can exert power. Power is a substantial part of stratification theories. Lenski formulated a more nuanced standpoint of power in terms of stratification, referring to the prejudices that arise from class and status distinctions. Lenski indicated that these prejudices become strongly institutionalised (Lukes, 1986:12). These prejudices exercise power!

\subsection{Conclusion on agency}

Power can be exercised by persons, groups, organisations or aspects of society. Foucault, Lukes, Poulantzas and Lenski each identified aspects of society as agents of power. The power of social constructs is clear from their arguments. Agents of power can therefore be humans but also non-humans. Power theories have different focuses. Some theories focus on power located at humans. There are also others that focus on the power exercised by organisations, 
structures, traditions, languages, norms, identity and practises. To this can be added the power that natural phenomena can exercise with regard to society. Therefore in this article the following kinds of agents which can exercise power are identified: active, created and natural powers (power here means "something with power"). Active powers are powers who act on their interpretation of their situation and in view thereof exercise power. Examples of such powers are individuals, groups and the members of organisations. Created powers are powers created by people to exercise social control. Examples are patterns, structures, organisations as structures, traditions, languages, norms, values, identity, arrangements, processes and practices. Natural powers are powers that are brought about by nature. Examples are climate, natural resources and the natural needs of people. The definition of power proposed in this article, is formulated in such a way that it will apply to all of these powers. The following section discusses the controlling effect of power exercised by powers - a well-debated issue.

\section{Power and control}

The question whether power implies control, actually asks how the freedom of people can be limited. Power prevents them to advance their own freedom. The freedom of people can be limited in different ways for example: by interfering with the available choices for example by limiting them; by structuring the available choices in such a way that a certain choice would have a larger probability to be made than another; by manipulating the choices in such a way that those that are executable form a specific set; and by limiting subordinates the capacity to choose. The components of the meaning of "freedom" are, however, just as complex as that of power. When and if an action is limiting, freedom and what coercion implies are controversial subjects. For instance, even within limiting measures, subordinates still keep the possibility to decide by themselves how they will react. Simmel (1986) also stresses this point with regard to power. The exercise of power to limit action cannot totally take away the subordinates' freedom of action. It can only cause the cost of certain actions to look much more expensive (Lukes, 1986:10). Morriss (1987:120) says:

If we are interested in somebody's freedom to do some specified thing, then making it costly or punishable to do it does not remove the power to do it, and so does not render someone unfree to do it. 


\subsection{Control by limiting freedom}

Morriss adopted a standpoint between that of Simmel and the one of Foucault that implies little freedom in the power relationship. Morriss (1987:122) writes: "You are free to do something if there are no demeaning restraints on your power to do it; you lack freedom in so far as restraints which are inappropriate to your status are imposed on you." On lack of freedom he writes:

A summary of this section would be that to be unfree is to be unable, where the constraint on the ability is considered to be particularly demeaning to the actor's self-respect: to say that one is unfree as well as unable is to imply that one is insulted as well as injured. (Morriss, 1987:119.)

He observes the reason for the different views on freedom among writers as follows: "My claim is, then, that accounts of freedom differ because the various authors are working with different notions of self-respect." (Morriss, 1987:118.) A man's perspective on how his freedom is injured, will depend on the view of his own dignity. But dignity is only one human interest. An injury to his freedom limits a man's capacity to promote his interests. The preceding is only a few remarks regarding the intense debate on how people's abilities are limited. Power theorising ought to demonstrate the way and extent of the limits the exercise of power put on people's choices. A common standpoint on this may be difficult to formulate because of the different premises on what freedom is. But the problem of controllability is related to people's capacity to interpret their situation and react on it. People interpret the exercise of power and act or react according to the outcome of the interpretation process. Different perspectives on this exist in the theorising on power.

\subsection{Control through the legitimisation of power}

Lenski holds the view that rulers overcome the possibility of the negative interpretation of their power by legitimising it. Power is a very effective medium to establish something, but an expensive medium in the sense that it can cause subordinates to become negative. Therefore, Lenski (1986:245) writes, “... those who seize power by force find it advantageous to legitimize their rule once effective organized opposition is eliminated". The power of the conqueror is then legitimised and justified. This legitimising is usually done by means of laws (usually the laws of the old dispensation can be used, because they justified the old regime!), by instruments determining public opinion, for instance incentives and threats, educational and religious institutions and the mass media and by the fact that, be- 
cause of the daily demands, the ordinary man cannot be continuously politically active (Lenski, 1986:245-247). Institutionalised power differs from open power in the sense that it is much more socially acceptable and less personal (Lenski, 1986:249-250).

\subsection{Control and a common interpretation process}

Arendt overcomes the problem of the negative interpretation of the exercise of power by viewing power as the outcome of a common interpretation process. She views power not as an instrument that rulers use to attain a goal (Arendt, 1986:68), but for her power is a situation in which a group of people think and act over the use of means to realise a goal. Power is the ability to agree on a common way of acting within free communication. For Arendt power reveals itself in commands that ensure freedom, in resistance against forces that threatens political freedom and in those revolutionary actions that establish new institutions of freedom (Habermas, 1986:77). Power comes forward in free intersubjectivity. This power feeds institutions that defend the tender structures of intersubjectivity.

Power is actualized only where word and deed have not parted company, where words are not empty and deeds not brutal, where words are not used to violate and destroy, but to establish relations and create new realities. (Arendt as quoted in Habermas, 1986:79.)

She (Arendt, 1986:68) also writes: "Power springs up whenever people get together and act in concert, but it derives its legitimacy from the initial getting together rather than from any action that then may follow." Habermas is of the opinion that Arendt makes too much of the origin of power and too little of the use thereof. He is of the opinion that the gain of the standpoint of Arendt lies in her accentuation that rulers obtain their power from subordinates. Habermas adds the use of power to the origin of power. He stresses the importance that power is loaned by rulers:

Power is a good for which political groups struggle and with which a political leadership manages things; but in a certain way both find this good already at hand; they don't produce it. This is the impotence of the powerful - they have to borrow their power from the producers of power. This is the credo of Hannah Arendt. (Habermas, 1986:87.)

Habermas also indicates a further weak point in Arendt's argumentation. He indicates that structural violence, that to a large extent entrenches itself, can unnoticeably limit and even block that commu- 
nication in which power is formed. Communication is not as free as Arendt has stated it in her standpoint (Habermas, 1986:88). Arendt also coupled the ruler and subordinate so closely together that it is scarcely possible to distinguish them from each other.

\subsection{Control through subordinates}

Wrong takes another viewpoint on the interpretation of power by the people involved. His ideas is only applicable to some kinds of power relationships, but it further illustrates the different views in the debate on the interpretation of power. Wrong accentuates two aspects of the power relationship. In his definition he emphasises that power let something really happens. Thus events can occur with or without the person with power actually doing something. Just the knowledge that the person with power can exercise power, can have effects on the subordinate, even if the person in power does not act actively. Secondly Wrong also emphasises the asymmetry of power and balance of power. Power does not only occur in the unequal relationship between the ruler and subordinate, but also where persons or groups have different powers over and against each other and control each other mutually. "Politics includes both a struggle for power and a struggle to limit, resist and escape from power." (Wrong, 1979:13.) Power is only successful if the subordinate joins in. Resistance let the power relationship fail. Wrong describes power therefore in view of the reaction of the subordinate. It is not necessary to define power in such a way. A definition of power must, however, accommodate the free interpretation process of the people being influenced.

Aron describe this free interpretation process by writing that power can only be exercised over other people's actions, not over them as persons. He therefore differ from Dahl's formulation that A can have power over B. He prefers a clearer qualification of the meaning of "power over". A can have power over the behaviour of B, but not over the person of B. He says: "It extends over certain men or certain groups, and not over others; it exercises command over certain kinds of behaviour by the objects of power, but not over others." (Aron, 1986:260.) The subordinate also influences powers. In the exercise of power the process of influence is reciprocal. To illustrate this point Simmel for example refers to the reciprocal relationship that exists between the hypnotiser and the hypnotised (Simmel, 1986:207). A human is never totally surrendered in a power relationship. The subordinate is always free to determine its own reaction in a power relationship. The powers themselves are also influenced by 
their exercise of power. Morriss illustrates this with the example of farmers who bargained for better food prices. Eventually they also had to pay more for food. The effect of their exercise of power rebounded on them (Morriss, 1987:115). Exchange theory gives special attention to this reciprocity of power relationships. To prevent resistance, rulers sometimes use power in such a way that the effects will be inconspicious.

\subsection{Conclusion on power and control}

People cannot be controlled directly - they always have freedom in their interpretation of the power relationship and to some extent what their reactive actions will be. To a large extent power depends on this interpretation of the subordinates of their situation. This must be accommodated in a definition of power. This interpretation on the exercise of power stems from an experience of being influenced. It is therefore important to have clarity on the relationship between power and influence.

\section{Power and influence}

Power and influence are two concepts closely related to each other. In defining power it must be distinguished from influence. Morriss (1987) thoroughly discusses the difference between influence and power. He gives certain meanings only to the concept influence and others only to power and says there are certain meanings these concepts share. According to him only the concept influence means: events are affected in a certain way; and deed of influence. Both the concepts influence and power mean: the ability to influence; and the person or thing that have influence or which influence others. Only the concept power means: control that is formally and publicly expressed as in legislation; and the ability to cause something in any manner.

\subsection{Affecting and influencing}

From this analysis Morriss concludes that power is not a thing (resources), also not an event (practising of power), but an ability. Power is a dispositional concept. It is about the disposition of someone. Influence is a disposition with a continuing effect. Over against that, power is a disposition with a conditional effect. The person with power can practise power when so preferred.

Morriss further says that influence is related to influencing and power to affecting. When influencing occurs without affecting some- 
thing, power was not practised. On the other hand, to affect something without influencing is the practise of power. Morriss therefore argues strongly for the use of the expression "power to" rather than "power over". He says for example that when we say: "He has power over (in connection with) the matter whether it is going to rain or not" we are actually speaking of influencing. If, however, we say: "He has power to produce rain" we speak of producing effects and that is true power (Morriss, 1987:33). Morriss indicates that the use of "power over" usually has the intention to refer to ability of the person in power to achieve his goals through the influencing of the subordinate. But actually "power over" refers that the goal of the person in power is to rule over the subordinate and to regulate his behaviour over a broad front. The expression "power over" actually only expresses the influencing aspect of the concept power and that is not a necessary part of the meaning of the concept. "Power to" is rather related to the core meaning of power - with the ability to affect something (Morriss, 1987:33).

\subsection{Powercauses effects}

Power is not one-directional, but it activates reaction. Sartre says: "While I attempt to free myself from the hold of the Other, the Other is trying to free himself from mine; while I seek to enslave the Other, the Other seeks to enslave me." (Sartre, 1956:475.) This reaction is not always clear. The influence of power can be recognised or misrecognised (for example in symbolic violence or habitus as explained by Bourdieu). Lukes (2005:122) explain it as follows:

In all these various ways, domination can induce and sustain internal constraints upon self-determination - ways of undermining and distorting people's confidence in and sense of self and of misleading and subverting their judgment as to how best to advance their interests. ... But that is to view social actors as simply the bearers of social roles, identifying their interests with the requirements of their roles.

Interpersonal power is much easier to qualify and therefore to resist, than impersonal power (Lukes: "third-dimensional power"). But influence is not about the overcoming of resistance (see discussion of Morriss, 2002:xxxii-xxxv). The formation of preferences, internalisation and hegemony are all influences in a certain way which cause effects - influence up to the virtuous resignation of Nietsche's slaves (Lukes, 2005:132). Power can be at work, inducing compliance by influencing desires and beliefs, without being "intelligent and intentional" (Lukes, 2005:136). Power influence to cause ef- 
fects. Power is the ability to have an effect. But what effect? Diverse opinions exist with regard to it. In the following section some of these perspectives are discussed.

\section{Power and the ability to affect}

A great deal of the debate over the definition of power deals with the effect of the exercise of power. In the early definitions the effect was related to the will of the ruler. In the course of time this issue was debated in depth.

\subsection{Power produc es effects}

Goldman defined power in view of the effect it creates, as follows: "S has power with respect to issue $E$ if and only (a) if $S$ wanted outcome $e$, then $e$ would occur, and (b) if $S$ wanted outcome not-e, then not-e would occur." (Goldman, 1986:159.) Russell also writes that power is in its core the production of intended effects on other people (Russell, 1986:19). Lukes reckon that power is more about the ability to produce effects than the production of effects themselves. According to him it is often not clear which effects were produced by power and which not (Lukes, 1986:1).

Wrong proposes a definition of power in which he tries to reconcile Russell's definition with that of Dahl. Wrong describes power as the ability of some persons to bring about intended and anticipated effects on others (Wrong, 1979:2). Thereby Wrong limits his definition to intended and anticipated influencing. He admits, however, that power nearly always have unintended and non-anticipated influencing as a result. He does not include this type of influencing in his definition, because, he states:

Power would be collapsed into social control and would include the diffuse control of the One by the Many as well as the relatively permanent past effects of power embodied in internalized norms (the superego), taken-for-granted beliefs and even language itself which, as contemporary linguistic philosophers have shown, contains built-in preconceptions, prejudgments and evaluations. (Wrong, 1979:252.)

However, he (Wrong, 1979:253) further writes: "Nevertheless, one can and should recognise that power is inherent in all social interaction, which consists of actors reciprocally producing effects on one another." Thus whilst Wrong senses that power is also related to unforeseen and unintended influencing, he is not prepared to accommodate it in his definition. The contribution of Wrong lies in his 
extension of the definition of power to emphasise on the capacity of people to bring about effects. He, however, hesitates before the problem of unforeseen and unintended influencing and doesn't give it a place in his definition. He also sees the production of effects only as the change of behaviour while it can also imply changes in opinions or beliefs.

\subsection{Poweras the ability to affect}

Giddens (1991), in his preference to speak of "power to" rather than "power over", formulated power as an agent with the ability to make a difference in the present state of affairs. Giddens pointed out that power is often viewed as stemming from the will of a person and that it is related to achieving wanted and intended outcomes. He pointed out that Parsons and Foucault view power as the property of a society or social community. Giddens infered that both these views on power are correct. Giddens was of the opinion that both these views can be joined by referring to resources. He (Giddens, 1991:15) said:

Resources (focused via signification and legitimation) are structured properties of social systems, drawn upon and reproduced by knowledgeable agents in the course of interaction.

He adds: "Resources are media through which power is exercised, as a routine element of the instantiation of conduct in social reproduction." (Giddens, 1991:16.) Giddens concludes that resources are embedded in the structure of society and that agents use these resources ingeniously to make a difference in the social course of events.

Giddens was against the identification of power only with conflict (as in Marxism) or only with domination (as in liberalism). He wrote:

Power is not necessarily linked with conflict in the sense of either division of interest or active struggle, and power is not inherently oppressive. ... Power is the capacity to achieve outcomes; whether or not these are connected to purely sectional interests is not germane to its definition. Power is not, as such, an obstacle to freedom or emancipation but is their very medium - although it would be foolish, of course, to ignore its constraining properties. The existence of power presumes structures of domination whereby power that 'flows smoothly' in processes of social reproduction (and is, as it were, 'unseen') operates. The development of force or its threat is thus not the type case of the use of power. (Giddens, 1991:257.) 
Giddens's definition of power expressed the dynamics of the exercising of power. His opinion, that it is about making a difference in the course of events, expressed a variety of the dynamic aspects of the exercising of power. Giddens, however, did not escape critique with the formulation he used. It is not clear in his formulation how the effects that is not produced by the exercising of power, must be distinguished from those which was produced by the exercising of power. Power implies the production of effects, but what type of effects?

\subsection{Conclusion on power and the ability to affect}

It is clear from the debate on the effects of power that it illustrates the incidence of power. Therefore the identification of effects is important in the defining of power. This problem is addressed in the proposed definition by distinguishing between influence and effect. Power has been exercised when both influence and effect have been realised. The effect, however, can only be accomplished through influence. The influence is directed at the actions and opinions of people with the goal to accomplish effects. These effects imply impacting on affairs and people. In the next section the insights of the preceding discussion is used to define power.

\section{Power defined}

In view of the previous discussion the following conclusions can be drawn:

- Power is about having an ability to accomplish an effect. The reference to effect is important to distinguish power clearly from the concept influence.

- Power can be exercised by different kinds of powers: active, created or natural. Active powers can for instance exercise power by means of their interpretation of a situation. Created powers are structures, patterns, processes, institutions, et cetera created by people to structure human life. In this structuring process the powers created by humans impact on human life. Natural powers like climate, needs and natural resources also affect humans. Power exists in many forms and must be defined according to that.

- Power is an ability. It is the capability to do something. It refers to a capacity the holder of power has. The proof of the power lies in the exercise of it, but it can also exist only by means of per- 
ceptions. The ability is in the first instance to influence people. It is a capacity to direct the actions and opinions of people.

- Power cannot intrude the freedom of people to interpret the exercise of power. People's reactions to the exercise of power can never be totally determined. Potentially humans always have the capacity to react according to their own views. The exercise of power is at the mercy of the reaction of those who are influenced with the aim to be affected.

- The influence exercised by power can only be on humans. Affairs cannot be affected directly. It must be done through firstly influencing humans who construct the ideas of affairs.

- Primarily power is about causing effects. Through influencing the goal of power is to affect affairs and people. Affairs refer to social constructs. Different aspects of people can be affected - actions, perceptions, thoughts, practices, beliefs, et cetera. This effect can be to stop change, start change or direct it.

In view of this, the proposed definition defines power firstly as an ability to influence. This ability arises from a possible situation of change that makes it possible for outcomes to occur. The influence is on people's actions and opinions. This means that people are free to interpret this influence which determines their reaction to the influence. Eventually power is also an ability to affect affairs and people, but it is mediated by the process of influence and reaction. The outcome of power is therefore not the result of the exercise of power, but the result of the reciprocal relationship between the power and the people under its influence. Therefore the definition proposed for power in this article is: Power is the ability, in view of the possibility of change, to influence the actions and opinions of people and so causes effects in affairs and people.

\section{List of references}

ARENDT, H. 1986. Communicative power. (In Lukes, S., ed. Power. Oxford: Blackwell. p. 59-74.)

ARON, R. 1986. Macht, power, pruissance: democratic prose or demonical poetry. (In Lukes, S., ed. Power. Oxford: Blackwell. p. 253-277.)

BACHRACH, P. \& BARATZ, M.S. 1963. Decisions and non-decisions: an analytical framework. American political science review, 57:632-642.

DAHL, R.A. 1986. Power as the control of behaviour. (In Lukes, S., ed. Power. Oxford: Blackwell. p. 37-58.)

FOUCAULT, M. 1986. Disciplinary power and subjection. (In Lukes, S., ed. Power. Oxford: Blackwell. p. 229-242.)

GIDDENS, A. 1991. The constitution of society. Cambridge: Polity. 
GOLDMAN, A.I. 1986. Toward a theory of social power. (In Lukes, S., ed. Power. Oxford: Blackwell. p. 156-202.)

HABERMAS, J. 1986. Hannah Arendt's communications concept of power. (In Lukes, S., ed. Power: Oxford: Blackwell. p. 75-93.)

LENSKI, G. 1966. Power: and privilege: a theory of social stratification. New York: McGraw-Hill.

LENSKI, G. 1986. Power: and privilege. (In Lukes, S., ed. Power. Oxford: Blackwell. p. 243-253.)

LUKES, S. 1974. Power: a radical view. London: Macmillan.

LUKES, S., ed. 1986. Power. Oxford: Blackwell.

LUKES, S. 2005. Power: a radical view. 2nd ed. Hampshire: Macmillan.

MORRISS, P. 1987. Power: a philosophical analysis. New York: St. Martin's.

MORRISS, P. 2002. Power: a philosophical analysis. 2nd ed. Manchester: Manchester University Press.

PARSONS, T. 1986. Power and the social system. (In Lukes, S., ed. Power. Oxford: Blackwell. p. 94-143.)

POULANTZAS, N. 1986. Class power. (In Lukes, S., ed. Power. Oxford: Blackwell. p. 144-155.)

RUSSELL, B. 1986. The forms of power. (In Lukes, S., ed. Power. Oxford: Blackwell. p. 19-27.)

SARTRE, J-P. 1956. Being and nothingness: a phenomenological essay on ontology. New York: Washington Square.

SIMMEL, G. 1986. Domination and freedom. (In Lukes, S., ed. Power. Oxford: Blackwell. p. 203-210.)

WEBER, M. 1947. The theory of social and economic organization. New York: Macmillam.

WEBER, M. 1962. Basic concepts in sociology. Londen: Owen.

WRONG, D.H. 1979. Power: its forms, bases and uses. Oxford: Blackwell.

ZAAIMAN, S.J. 2001. Plaaslike magsopset teoretisering: 'n sintetiese bydrae as gids vir die ontleding van die Suid-Afrikaanse plaaslike magsopsette. Stellenbosch: Universiteit van Stellenbosch. (Ongepubliseerde D.Phil.proefskrif.)

\section{Key concepts:}

change

influence

power

social power

Kernbegrippe:

invloed

mag

sosiale mag

verandering 
